\title{
Faktor Pendorong Respon Komunitas Pondok Pesantren Madura Terhadap Bank Syariah
}

\section{Iskandar}

STKIP PGRI Sumenep, Indonesia

*Email korenpondensi: iskandarjohar@yahoo.co.id

\begin{abstract}
This study aimed to determine how the community of Islamic boarding schools responds to Islamic banks and what factors that were drived the response of the boarding school community to Islamic banks. The procedure of data collection in this study was obtained using the interview method, and supported by documentation and observation, and then the data was analyzed to obtain conclusions and verification. The results of this study explained that there were two groups of Islamic boarding school community responses to Islamic banks. first, the community is responsive to Islamic banks, and second, the community is less responsive to Islamic banks. the factors of islamic boarding school community to Islamic banks include: the community's view of bank interest law, the policy of head master of the Islamic boarding school, the introduction and dissemination of Islamic banking, access to Islamic banks, and the relationship between the values of Islamic boarding schools.
\end{abstract}

Keywords: Response, Islamic Boarding School Community, Islamic Bank

\begin{abstract}
Abstrak
Penelitian ini bertujuan untuk mengetahui bagaimana respon komunitas pondok pesantren terhadap bank syariah dan faktor pendorong respons komunitas pondok pesantren terhadap bank syariah. Prosedur pengumpulan data dalam penelitian ini diperoleh dengan menggunakan metode wawancara, dan didukung oleh dokumentasi dan observasi, kemudian data dianalisa untuk diperoleh kesimpulan dan verifikasi. Hasil penelitian menjelaskan bahwa terdapat dua kelompok respon komunitas pondok pesantren terhadap bank syariah. Yaitu: komunitas responsif terhadap bank syariah dan komunitas kurang responsif terhadap bank syariah. Sedangkan faktor pendorong respon komunitas pondok pesantren terhadap bank syariah antaralain: pandangan komunitas terhadap hukum bunga bank, kebijakan kiyai pimpinan pondok pesantren, pengenalan dan sosialisasi tentang perbankan syariah, akses terhadap bank syariah, keterkaitan antara nilai-nilai pondok pesantren dengan bank syariah.
\end{abstract}

Kata kunci: Respon, Komunitas Pondok pesantren, Bank syariah

Saran sitasi: Iskandar. (2019). Faktor Pendorong Respon Komunitas Pondok Pesantren Madura Terhadap Bank Syariah. Jurnal Ilmiah Ekonomi Islam, 5(01), 66-72. doi: http://dx.doi.org/10.29040/jiei.v5i01.363

DOI: http://dx.doi.org/10.29040/jiei.v5i01.363

\section{Pendahuluan}

Perbankan memiliki peranan vital sebagai lembaga keuangan dalam struktur perekonomian suatu negara (Uzair Muhammad, 1980). Selain sebagai lembaga intermediary, (penghimpun dana surplus masyarakat, dan pemberi pembiayaan bagi masyarakat yang mengalami defisit dana), perbankan juga memberikan beberapa pelayanan 
jasa yang memberi kemudahan pada nasabahnya. Maka tidak salah jika keberadaan perbankan sangat dibutuhkan dalam kehidupan berekonomi masyarakat, dan agama Islam juga berperan mengatur lembaga keuangan perbankan, karena ia merupakan bagian penting dari dinamika perekonomian masyarakat.

Terkait kegiatan operasional dan produk perbankan, Islam melarang adanya praktik yang merugikan dan mengeksploitasi antar satu sama lain. Tidak sebagaimana yang telah ada pada bank konvensional, Islam sangat melarang praktik pemberian bunga pada pinjaman. Menurut Maududi, institusi bunga merupakan sumber bahaya dan kejahatan, demikian menurut Karim, secara sosial istitusi bunga merusak semangat berkhidmat kepada masyarakat. Orang akan enggan berbuat apapun kecuali yang memberi keuntungan bagi diri sendiri. Keperluan seseorang dianggap peluang bagi orang lain untuk meraup keuntungan. Kepentingan orang kaya dianggap bertentangan dengan kepentingan orang miskin (Karim, Adiwarman A., 2004).

Berbeda dengan perbankan yang berbasis bunga dan bisa bersifat zero sum game, Islam menawarkan sebuah sistem yang bersifat positivesum game dimana semua pihak akan mendapat kemenangan atau paling tidak terdapat kemungkinan untuk memperoleh laba ataupun mengalami kerugian secara bersama-sama (Bakar M.D., dan Ali E.R.A.A, 2008:22). Sistem tersebut yang menjadi prinsip dasar di dalam perbankan Islam, yakni prinsip yang berasaskan interest-free banking (bank bebas bunga) dan berlandaskan mudharabah atau profit and loss sharing yang menjadi core product bank Islam (Uzair Muhammad, 1980).

Seiring perjalanannya, bank Islam terus mengalami peningkatan. Salah satu faktor utama tumbuh pesatnya perkembangan perbankan Islam dalam sejarah perjalanan dunia perbankan modern adalah perhatian besar negara-negara Islam terhadap penyegaran kembali identitas Islam dengan praktik-praktik syariah yang pernah diterapkan dalam kehidupan ekonomi masyarakat muslim (Iqbal, Zamir, 2002), sekaligus sebagai bentuk kritik terhadap bunga yang sangat menyengsarakan dan merugikan sebagian pihak masyarakat.

Perkembangan perbankan Islam dimulai pada abad ke-19 sebagai sebuah kritik atas bank barat yang berdasarkan riba (western intererest-based bank) yang mulai dibangun di berbagai negara berpenduduk mayoritas muslim (Saeed, Abdullah 1996). Keberadaan western intererest-based bank tersebut mendapatkan pertentangan dari kaum neorevivalist (Saeed, Abdullah 1996:5), seperti Muhammad Rashid Ridha, Muhammad Abduh, Hasan Al-Banna, Sayyid Qutb, dan Abu al-A'la Mawdudi yang menginterpretasikan serta menetapkan bunga bank sebagai bentuk riba yang jelas terlarang di dalam Islam. Perlawanan dan pergerakan kaum neo-revivalist inilah faktor yang paling utama yang memberikan pengaruh terhadap perkembangan teori perbankan Islam dan kemunculan maupun perkembangan bank Islam dengan produk-produk investasi yang bersifat Islami (Saeed, Abdullah, 2006).

Pesatnya perkembangan perbankan Islam dewasa ini, tidak hanya mewarnai dunia bisnis negara-negara dengan penduduk muslim mayoritas. Dalam dunia bisnis negara-negara Barat sekalipun, trend perkembangan perbankan Islam bukan merupakan suatu hal yang baru. Kini terdapat bank-bank besar di negara Barat, seperti Citibank, ANZ Bank, Chase Manhattan Bank dan Jardin Fleming telah membuka Islamic window agar dapat memberikan jasa-jasa perbankan yang sesuai syariat Islam (Karim, Adiwarman A, 2009:24).

Di Indonesia perkembangan perbankan Islam dimulai dari inspirasi para tokoh agama yang ingin segera mendirikan bank syariah dan bebas dari prktik bunga hingga berlakunya UU No. 7 1992 tentang perbankan yang mulai mengakomodir keberadaan bank syariah, serta diberlakukannya UU No. 10 Tahun 1998 yang mencakup segi kelembagaan maupun landasan operasional syariahnya (Briefcase Book, 2007:24).

Ketidakmerataan perluasan jaringan perbankan syariah sangat mencolok terjadi di daerah Madura Jawa Timur dimana hingga saat 
ini hanya terdapat 1 kantor cabang bank umum syariah dan 6 kantor cabang pembantu yang terletak di beberapa kota/kabupaten di Madura (https://bps.go.id). Potensi jumlah penduduk muslim mayoritas yang tersebar hampir ke seluruh kota/kabupaten, serta besarnya jumlah pesantren yang berpotensi menjadikan asatidz (guru) dan alumni sebagai syariah loyalis, atau sedikitnya floating more syariah, karena pendidikan yang diterapkan sangat berkaitan dengan masalah syariah seperti fiqh dan muamalah (Madjid, Nurcholis, 1997:8), tidak didukung oleh distribusi jaringan kantor bank syariah.

Keberadaan pesantren seyogyanya menjadi lahan sekaligus mitra strategis bagi perbankan syariah untuk mengembangkan jaringannya di pulau Madura dan beberapa pulau lain yang tersebar di dalamnya pondok pesantren. Meski secara institusional lebih dominan berfungsi sebagai lembaga pendidikan, akan tetapi, di dalam pesantren terdapat kesamaan nilai-nilai sebagaimana diusung oleh perbankan syariah.

Sebagaimana bank syariah yang memiliki prinsip berdasarkan syariat Islam, serta dalam melakukan bisnis tidak hanya berorientasi profit semata, melainkan juga berorientasi falah dan nilai-nilai ukhrawi, karena akan berdampak pada pertanggungjawaban seseorang di dunia dan akhirat (Briefcase Book, 2007:12), pada pondok pesantrenpun, sudah barang tentu nilai-nilai pendidikan yang terkandung di dalamnya berorientasi akhirat, meski demikian, hal-hal yang berkaitan dengan duniawi tidak luput dari perhatiannya. Maka dari deskripsi di atas dapat ditarik kesimpulan bahwa fungsi pondok pesantren dan perbankan syariah, memiliki keterkaitan tujuan dan niai-nilai yang tidak jauh berbeda yakni mensejahterakan masyarakat berdasarkan prinsip-prinsip syariah, meski keduanya merupakan lembaga dengan kegiatan yang sama sekali berbeda.

Pesantren memiliki peran dan fungsi sosial pemberdayaan masyarakat sebagaimana perbankan syariah yang berpegang teguh pada prinsip mensejahterakan rakyat, yakni dengan mengutamakan mobilisasi dana dari golongan menengah dan ritel, memperbesar portofolio pembiayaan untuk skala kecil dan menengah, serta mendorong terwujudnya manajemen zakat, infak, dan sedekah yang lebih efektif sebagai cerminan kepada kepedulian sosial,

Pasar modal syariah merupakan salah satu alternatif investasi dengan saham syariah sebagai instrumen investasi yang menyatakan bukti penyertaan kepemilikan dalam perusahaanperusahaan yang berbasis syariah. Tandelilin (2011) mengemukakan investasi bisa didefinisikan sebagai komitmen sejumlah uang atau sumber daya lainnya yang dilakukan saat ini (present time) dengan harapan memperoleh manfaat (benefit) dikemudian hari (in future).

\section{Metode Penelitian}

Jenis penelitian ini tergolong ke dalam penelitian deskriptif analitik yang dilakukan secara intensif, terperinci dan mendalam dengan terjun langsung ke lapangan (field research) dan dikaji mendalam secara kualitif (Arikunto, Suharsimi, 2006:11). Penelitian deskriptif dimaksudkan untuk menjelaskan respon komunitas pondok pesantren terhadap bank syariah. Sedangkan analitik dimaksudkan untuk menjelaskan mengapa dan faktor apa saja yang melatarbelakangi komunitas pondok pesantren memberikan respon tersebut.

Metode penelitian kualitatif menurut Bogdan dan Taylor, diartikan sebagai prosedur penelitian yang menghasilkan data deskriptif yaitu data berupa kata-kata tertulis atau lisan dari orangorang dan perilaku yang diamati (Moleong, L.J, 2001:3). Penelitian kualitatif memandang objek yang diteliti secara holistik. Sebagai penelitian kualitatif, maka data yang dihasilkan dari penelitian kualitatif berupa data deskriptif, yaitu data yang berupa kata-kata tertulis ataupun lisan dari orang-orang dan perilaku yang diamati.

Penelitian kualitatif ini diarahkan pada latar dan subjek penelitian secara holistik dan kontekstual. Holistik berarti dengan berada dilapangan, dimana dengannya peniliti akan mampu memahami konteks data dalam 
keseluruhan situasi, sehingga mendapat pandangan secara menyeluruh. Sedangkan kontekstual berarti peneliti dapat mengumpulkan dan memcatat data secara rinci mengenai respon komunitas pesantren beserta faktor-faktor yang melatarbelakangi respon tersebut terhadap bank.

Pendekatan yang digunakan dalam penelitian ini adalah pendekatan fenomenologi. Penggunaan pendekatan ini bertujuan untuk memahami Respon komunitas pesantren terhadap bank syariah. Dalam penelitian ini dilakukan wawancara langsung terhadap komunitas pesantren yang meliputi kiyai, ustadz/guru, dan santri terkait respon mereka terhadap bank syariah. Disamping itu, pendekatan ini juga bertujuan untuk memperoleh pemahaman dan penafsiran secara mendalam terkait argumentasi dan faktor-faktor yang melatarbelakangi respon tersebut. Pendekatan fenomenologi memandang objek kajiannya sebagai kebulatan yang utuh, tidak terpisah dengan objek lainnya, dengan demikian pendekatan fenomenologi menuntut pendekatan yang holistik, bukan pendekatan yang parsial. Peneliti dalam pandangan fenomenologi berusaha memahami arti peristiwa dan kaitannya terhadap orang-orang dalam situasi-situasi tertentu.

Lokasi penelitian ini adalah Pondok Pesantren Al-Amien Prenduan dan Pondok Pesantren Annuqoyyah Guluk-Guluk. Sumber data pada penelitian ini adalah kata-kata dan tindakan dari komunitas pesantren Al-Amien dan An-Nuqoyyah Guluk-Guluk meliputi kiyai, ustadz/guru, santri, dan masyarakat sekitar, sebagai sumber data person yang didukung oleh pengamatan langsung oleh peneliti sebagai sumber data place, serta dokumen tertulis baik berupa catatan lapangan, jurnal, arsip administrasi, data statistik, majalah, buku dan lainnya sebagai sumber data paper.

Prosedur pengumpulan data dilakukan dengan mengadakan wawancara mendalam untuk mendapatkan informasi mengenai seluruh aspek yang diteliti dan relevan dengan masalah penelitian. Selanujutnya pengkajian atas berbagai dokumen resmi baik yang bersifat internal maupun eksternal. Bersifat internal dalam artian pengkajian langsung atas dokumen, misal arsip aktif maupun pasif, sedangkan bersifat eksternal dalam artian pengkajian terhadap sumber-sumber pendukung atas pengkajian dokumen seperti arsip berita. Prosedur lainnya dilakuakan observasi untuk memperoleh informasi dengan cara meninjau objek penelitia untuk melihat relitas yang terjadi dilapangan. Instrument yang digunakan untuk observasi berupa lembar pengamatan (observation cheklist).

Untuk mengetahui kesimpulan dari penelitian ini dilakukan analisis komprehensif atas data-data yang diperoleh. Karena temuan-temuan penelitian memerlukan pembahasan lebih lanjut dan memerlukan penafsiran lebih dalam untuk menemukan makna di balik fakta yang ada.

\section{Hasil dan Pembahasan}

Pondok pesantren (Ponpes) secara teknis berarti lembaga pendidikan Islam yang mengajarkan ilmu-ilmu keislaman, dipimpin oleh kiyai sebagai pemangku/pemilik Ponpes dan dibantu oleh asatidz/ustadz (guru) yang mengajarkan ilmu keislaman kepada santri, melalui metode dan teknis yang khas. Di dalam Ponpes selalu ada elemen kiyai, santri, masjid, tempat tinggal santri, teknik pengajaran yang khas dan kitab-kitab rujukan (Halim dkk, 2009:247), sebagaimana gambaran mengenai pengertian pondok pesantren di atas, pondok pesantren Al-Amien dan Annuqoyah merupakan dua lembaga pendidikan yang mengajarkan ilmuilmu keislaman dengan dipimpin oleh kiyai dan dibantu oleh asatidz/ustadz (guru) yang mengajarkan ilmu keislaman kepada santri. kedua pondok pesantren tersebut memiliki elemen sebagaimana kebanyakan pondok pesantren, yakni terdiri dari santri, asrama atau tempat tinggal santri, serta kiyai selaku pimpinan pesantren tersebut (Haedari, Amin, 2004:14).

Meski kedua pondok pesantren di atas lebih dominan berfungsi sebagai lembaga pendidikan, akan tetapi, pada program utama yang dijalankan oleh kedua pondok pesantren tersebut tidak bertumpu pada proses pendidikan semata, kedua 
pondok pesantren tersebut terlibat aktif dalam pengembangan ekonomi dan pemberdayaan masyarakat. Selain sebagai lembaga pendidikan, pondok pesantren Al-Amien Prenduan dan Annuqoyah Guluk-guluk juga berfungsi sebagai lembaga dakwah. karenanya menurut Haedari, bahwa pesantren memiliki peran penting sebagai agen pembaharuan sosial (Haedari, Amin, 2004:12).

Secara geografis, pondok pesantren AlAmien Prenduan dan pondok pesantren Annuqoyah Guluk-guluk terletak di kabupaten yang sama yaitu kabupaten Sumenep dengan keamatan yang berbeda. Pondok pesantren AlAmien berada di desa Prenduan, Kecamatan Pragaan Kabupaten Sumenep. Sedangkan pondok pesantren Annuqayah berada di desa GulukGuluk, kecamatan Guluk-guluk kabupaten Sumenep. Meski letak kedua pesantren ini jauh dari pusat kota Sumenep akan tetapi akses terhadap unit bank dan kantor kas baik syariah maupun konvensional sangat terjangkau. Karena kedua pesantren berada tidak jauh dari kecamatan.

\section{a. Respon Komunitas Pondok Pesantren Terhadap Bank Syariah}

Respon berarti suatu tanggapan; reaksi atau jawaban atas suatu objek (Departemen Pendidikan dan Kebudayaan, 1997:838). Berdasarkan data hasil wawancara penulis bersama responden, secara umum respon komunitas pondok pesantren terhadap bank syariah berdasarkan stimulus berupa instrumen wawancara yang diajukan oleh penulis dapat digolongkan ke dalam dua kelompok. Pertama, komunitas pondok pesantren yang responsif berhubungan dengan bank syariah, Kedua, komunitas pondok pesantren yang kurang responsif dan tidak berhubungan dengan bank syariah.

Komunitas Pondok Pesantren yang tanggap dan responsif terhadap bank syariah sebagian besar terdiri dari jajaran kiyai sebagai pemangku jabatan penting dalam struktur kepengurusan pondok pesantren. Hal ini terindikasi sikap mereka yang berhubungan dengan menabung di bank syariah. Bahkan, sikap loyalitas yang tinggi terhadap bank syariah, disertai dengan sikap ajakan responden terhadap komunitas pondok pesantren yang lain untuk turut serta menabung di bank syariah. Seperti dengan mengeluarkan kebijakan kewajiban pembayaran SPP santri melalui bank syariah.

Faktor utama kecenderungan mereka berhubungan dengan bank syariah adalah pernyataan mereka bahwa bunga bank sebagaimana terdapat di bank konvensional adalah haram berdasarkan dalil dari nash alquran dan Sunnah yang mereka pelajari dari kitab fiqh. Pengertian bunga yang secara bahasa, adalah terjemahan dari kata interest, dan secara istilah berarti: "interest is a charge for a financial loan, usually a percentage of the amount loaned," atau tanggungan pada pinjaman uang yang biasanya dinyatakan dengan persentase dari uang yang dipinjamkan, hal ini menurut Muhammad, berdasarkan pengertiannya, menjadi jelas bahwa bunga yang dipraktikkan dalam bank konvensional tidak berbeda dengan praktik riba yang secara tegas dilarang dalam Islam. Kesamaan itu menurut Muhammad, sulit dibantah, apalagi secara aplikasi sistem bunga dalam perbankan lebih banyak dirasa mudlaratnya dari pada manfaatnya (Muhammad, 2005).

Selanjutnya komunitas pondok pesantren yang kurang responsive terhadap bank syariah yang sebagian besar terdiri dari para santri dan sebagian guru/asatidz. Indikator tidak responnya komunitas tersebut terlihat dari sikap mereka yang menabung di bank konvensional dan enggan menabung di bank syariah. Meski terdapat banyak faktor yang melatarbelakangi tidak responnya mereka terhadap bank syariah faktor yang menarik adala pernyataan bahwa bunga bank menurut mereka dibolehkan sepanjang pemakaian bunga dalam praktik keuangan tidak dalam porsi yang besar atau karena terpaksa harus menggunakan bunga tersebut.

Berikut beberapa faktor pendorong respon komunitas pondok pesantren terhadap bank syariah yang penulis rangkum ke dalam sub bab selanjutnya.

\section{b. Faktor Pendorong Respon Komunitas Pesantren Terhadap Bank Syariah}


Berdasarkan hasil wawancara penulis bersama para responden terkait hal-hal yang berkaitan dengan respon komunitas pondok pesantren terhadap bank syariah, terdapat beberapa temuan yang dapat mengindikasikan temuan tersebut sebagai faktor pendorong respon mereka terhadap bank syariah, dimana temuan tersebut dapat diuraikan dengan penjelasan sebagaimana berikut:

1) Pandangan Komunitas Terhadap Hukum Bunga Bank

Identifikasi pandangan komunitas pondok pesantren terhadap bunga bank, adalah indikasi kuat sebagai faktor pendorong respon mereka terhadap bank syariah. Sebagaimana dipaparkan pada pembahasan dan hasil temuan di atas, bahwa komunitas pondok pesantren yang beranggapan bunga bank sama dengan riba dan hukumnya adalah haram, menjadi salah satu alasan responden menabung di bank syariah. Namun meski demikian, hal ini bukanlah faktor utama yang mendorong mereka dalam berhubungan dengan bank syariah dan mengabaikan bank konvensional. Bahkan, sebagian responden masih menabung di bank konvensional, meski pada saat bersamaan mereka beranggapan bahwa bunga bank adalah haram.

Demikian terkait alasan pandangan hukum bunga bank oleh responden, tidak menjadi satusatunya faktor kuat yang menjamin para responden dalam berhubungan dengan bank syariah. Bahkan, responden yang tergolong berpikir pragmatis, cenderung mengabaikan faktor ideologis tersebut, dan beralih pada beberapa faktor yang menguntungkannya.

2) Kebijakan Kiyai Pimpinan Pondok Pesantren

Kiyai memiliki peranan penting dalam menentukan kebijakan pondok pesantren yang akan berimplikasi pada dihormati dan dipatuhinya kebijakan tersebut. Sebagaimana di pondok pesantren Al-Amien Prenduan dan Annuqoyah Guluk-guluk, kebijakan kiyai pimpinan pondok pesantren bersama majlis kiyai yang lainnya dalam menentukan wajibnya pembayaran SPP santri melalui bank, merupakan faktor yang secara otomatis mendorong para komunitas pondok pesantren terutama kalangan santri dalam berhubungan dengan bank syariah ataupun bank konvensional.

3) Pengenalan dan Sosialisasi Tentang Perbankan Syariah

Ketidakmerataan perluasan jaringan perbankan syariah yang sangat mencolok di daerah Madura Jawa Timur dimana pada dasarnya tidak terlalu signiikan mengurangi pengetahuan dan pengenalan komunitas pondok pesantren terhadap bank syariah. Akan tetapi pengenalan akan nama belumlah cukup mengindikasikan pemahaman sebagian besar dari komunitas pondok pesantren terhadap perbankan syariah, baik secara produk maupun mekanisme operasionalnya.

Upaya pengembangan perbankan syariah yang tidak lepas dari halangan dan tantangan dimana faktor dominannya adalah lemahnya pemahaman masyarakat terhadap kegiatan operasional bank syariah (Antonio, Muhammad Syafi'i, (2009:224-225), hal ini masih juga terjadi pada sebagian besar komunitas pondok pesantren. Meski terdapat mata pelajaran fiqih bab mu'amalah yang diterapkan di pondok pesantren, hal itu tidaklah cukup kuat, menjadi faktor pendorong komunitas untuk berhubungan dengan bank syariah.

Dibutuhkan sosialisasi tentang perbankan syariah terhadap komunitas pondok pesantren. Hal ini diakui salah seorang responden dari komunitas pondok pesantren bahwa keinginan untuk menjadi nasabah bank syariah didorong oleh pengetahuannya tentang bank syariah melalui seminar yang sering diadakan oleh sosialisasi tentang perbankan syariah yang diprakarsai oleh pondok pesantren bekerjasama dengan bank syariah, ditambah lagi dengan ilmu yang dia peroleh dari bangku kuliyah pada jurusan muamalah (Riadi, 2011).

4) Akses Terhadap Bank Syariah

Sulitnya akses terhadap bank syariah sebagaimana disinggung pada hasil temuan dan pembahasan di atas, menjadi faktor keluhan selanjutnya para responden yang mendorong respon mereka terhadap bank syariah. Hampir 
sebagian besar responden, berdasarkan data yang diperoleh dari hasil wawancara mereka berpendapat bahwa halangan mereka berhubungan dengan bank syariah, karena sulitnya akses dan sedikitnya jaringan bank syariah.

5) Keterkaitan antara nilai-nilai pondok pesantren dengan bank syariah.

Faktor lain yang menjadi keunikan tersendiri bagi pondok pesantren dalam mendorong komunitasnya merespon positif terhadap bank syariah, yakni nilai yang dimiliki oleh bank syariah yang sejalan dengan nilai yang terdapat di pondok pesantren yakni menjujung tinggi syariat Islam dalam bermuamalah. Hal ini yang kemudian menjadi daya tarik tersendiri bagi komunitas pondok pesantren untuk berhubungan dengan bank syariah.

\section{Kesimpulan}

Berdasarkan pembahasan di atas, maka dapat disimpulkan, bahwa sikap dan tindakan komunitas pondok pesantren terhadap bank syariah dapat dikelompokkan ke dalam dua kategori, antara lain: (1) Sikap dan tindakan responsif komunitas pondok pesantren terhadap bank syariah. (2) sikap dan tindakan komunitas pondok pesantren yang tidak responsif terhadap bank syariah. Adapun faktor pendorong respon dan tidaknya komunitas pondok pesantren antara lain: pandangan komunitas terhadap hukum bunga bank, kebijakan kiyai pimpinan pondok pesantren, pengenalan dan sosialisasi tentang perbankan syariah, akses terhadap bank syariah, dan keterkaitan antara nilai-nilai pondok pesantren dengan bank syariah.

\section{Daftar Pustaka}

Antonio, Muhammad Syafi'i. 2009. Bank Syariah dari Teori ke Praktik, Jakarta: Gema Insani Press.

Arikunto, Suharsimi. 2006. Prosedur Penelitian Suatu Pendekatan Praktik, Jakarta: Renika Cipta.
Bakar, M.D, "Riba and Islamic Banking and Finance" dalam Bakar M.D., dan Ali E.R.A.A. 2008. Essential Readings In Islamic Finance, Malaysia: CERT Publication.

Briefcase Book. 2007. Edukasi Profesional Bank Syariah: Konsep dan Implementasi, Jakarta: Renaisan.

Bungin, Burhan. 2008. Analisis Data Penelitian Kualitatif : Pemahaman Filosofis dan Metodologis ke Arah Penguasaan Model Aplikasi, Jakarta: Raja Grafindo.

Departemen Pendidikan dan Kebudayaan. 1997. Kamus Besar Bahasa Indonesia, Jakarta: Balai Pustaka.

Haedari, Amin. 2004. Masa Depan Pesantren: dalam Tantangan Modernis dan Tantangan kompleksitas global, Jakarta: IRD Press.

Halim dkk. 2009. Manajemen Pesantren, Yogyakarta: Pustaka Pesantren.

Karim, Adiwarman, A. 2009. Bank Islam Analisis Fiqih dan Keuangan, Jakarta: PT. RajaGrafindo Persada.

Madjid, Nurcholis. 1997. Bilik-bilik Pesantren Sebuah Potret Perjalanan, Jakarta: Paramadina.

Moleong, L.J. 2001. Metodologi Penelitian Kualitatif, Bandung: PT. Remaja Rosda Karya.

Muhammad. 2005. Manajemen Bank Syariah, Yogyakarta: UPP AMP YKPN.

Saeed, Abdullah (1996), Islamic Banking and Interest, A study of prohibition of riba and its contemporary interpretation, New York: E.J Brill.

Sarker, M.A.A, "Islamic Business Contract, Agency Problem And The Theory Of Islamic Firm", International Journal Of Islamic Financial Services, Vol.1 No.2,

Uzair Muhammad. 1980. Some Conceptual and Practical Aspects of Interest Free Banking dalam Khursyid Ahmad Studies in Islamic Economic, United Kingdom: The Islamic Foundation.

Wijaya, Afif. 2009. Market Segmentation and Consumer Behavior Toward Islamic Bank, (Ekbisi Jurnal Ekonomi dan Bisnis Islam), Vol. 3 Jakarta 